\title{
Editorial: political abuse of psychiatry in authoritarian systems
}

\author{
J. P. Tobin* \\ Consultant Psychiatrist
}

We are painfully aware: Psychiatry in some states of the international community is often used to subvert the political and legal guarantees of the freedom of the individual and to violate seriously his human and legal rights (Daes, 1986).

Objective. It can be politically convenient to incarcerate political opponents in a psychiatric hospital. It saves any potential political embarrassment that a judicial trial may present. It also undermines the credibility of opponents by labelling them with the stigma of being mentally insane. For this to occur, there has to be the acquiescence of mental health professionals and a subservient legal system.

Method. This article examines the abuse of psychiatry in two authoritarian systems, Russia and China.

Result. New diagnostic categories such as sluggish schizophrenia were created to facilitate the silencing of dissenters and were a source of self-deception for psychiatrist to placate their consciences as they operated as a tool of oppression on behalf of a political system.

Conclusion. If we do not know the past, we will be condemned to repeat it.

Received 4 September 2012; Revised 22 January 2013; Accepted 24 January 2013; First published online 23 May 2013

Key words: Ankangs, cultural revolution, geneva initiative on psychiatry, paranoid psychosis, political dissident, serbski institutes, sluggish schizophrenia, stalinist era, state repression, World Psychiatric Association.

\section{Introduction}

In Ireland, there appears to be no political abuse of psychiatry. There are arguments that psychiatry in Ireland has been utilised as a form of social control in the past. We live in a country that has a recent history of incarcerating people who offended the social mores of the time, in places such as the Magdalen Laundries and in the old asylums. Under the 1945 Mental Treatment Act, people with alcohol problems were frequently deprived of their liberty. With this kind of history, it is incumbent upon us to be aware of the potential abuse of psychiatry for political purposes and to challenge our colleagues in other countries where it is a problem. There are two sample countries that are worth examining in detail in order to understand how the abuse of psychiatry arises: Russia and China.

There is an inbuilt potential for human rights abuse in psychiatry that surpasses that in any other field of medicine (Bloch \& Reddaway, 1977). The diagnosis of a mental illness permits the state to detain an individual against their will and to insist on treatment in the wider interest of society. Psychiatry can be used

* Address for correspondence: J. P. Tobin, BSc, MB, LLM, MRCPsch, FRCPC, Consultant Psychiatrist, Bloomfield Health Services, Stocking Lane, Rathfarnham, Dublin 16, Ireland.

(Email: tobinjp3@gmail.com) to bypass the normal legal procedures for assessing guilt or innocence and to allow for detention without the odium attached to a political trial (British Medical Association, 1992). Admission to a psychiatric hospital in many countries deprives the dissident of the opportunity to utilise legal recourse to their detention and they can be considered as non-imputable, as it can be stated that they are too ill to attend (Bloch \& Chadoff, 1991). If a psychiatric diagnosis is attached to a dissenter, it can lead to a level of doubt as to the rationality of his/her political or social views. For example, colonial governments in Africa used psychiatry to try to demonstrate that those who were agitating for independence were psychopathic (Njenga, 2002). Psychiatric labelling serves to stigmatise and socially marginalise the dissidents and social opponents of the ruling system. US doctors in the 19th century diagnosed slaves who had a propensity to run away as suffering from drapetomania. Slaves who refused to work and who destroyed property suffered from drysaesthesia aettiopis (Hickling, 2002). Psychiatry has historically kept changing its diagnostic categories. This allows for a wider spectrum of views as to what is and what is not illness. In these circumstances, it is easier to describe dissenting political views as paranoia and to allow for the manipulation of psychiatry for political purposes. It also facilitates repressive regimes to 
detain unwanted persons indefinitely. As they are in hospital, there is little discussion as to the length of time that they need to be detained. It is perceived that discharge is a medical decision and not a legal or political decision.

\section{Psychiatry in Russia and the Soviet Union}

Abuses of psychiatry in Russia are recorded from Tsarist times, pre-dating the formation of the Soviet Union in 1917. In 1836, the Russian philosopher, Pyotr Chaadayev, angered the Tsar Nicholas I by publishing an article criticising the backwardness of Russian society. He was declared insane and he was placed under house arrest for a year (Medvedev \& Medvedev, 1971). An awareness of the abuse of psychiatry influenced Anton Chekov, a medical doctor, to write the short story Ward No: 6, in 1892. It was about a sane public figure incarcerated in a psychiatric institution by the Okhrana, who were the tsarist secret police.

Under Marxist/Leninist philosophy, mental illness was the result of an unjust capitalistic system and exploitation. As a result, the theory was that mental illness should decline under communism. Hence, its continuing presence was perceived as a failure of an individual's social development (Gordon \& Meux, 2000).

During the Stalinist period, when the oppression in the Soviet Union reached its zenith, there was little reason to utilise psychiatry to remove supposed enemies of the people, when there were gulags and mass executions to remove those that were politically suspect. However, it was during this period that the Kazan Special Psychiatric Hospital was established. It was not under the jurisdiction of the health authorities, instead it was under the control of the Ministry of Internal Affairs. The NKVD (the forerunner of the KGB) determined the psychiatric decisions regarding admission, discharge and treatment (Ougrin et al. 2006). After the annexation of Estonia in 1939, the Estonian President, Pats, was detained at this facility from 1941 until 1956. The argument often presented against obtaining an independent psychiatric opinion was that it was not necessary, as all psychiatrists were independent. Even after their discharge, the dissenter had to live with the stigma associated with a psychiatric admission. They would frequently find that their marriage and employment were gone. They could have difficulties finding accommodation.

As bad as incarceration was in a psychiatric institution during Stalin's rule, it was frequently more preferable to the gulags, were life expectancy to be significantly reduced. One victim, Nuam Korzhavin, recalled that the doctors were benevolent and not punitive. He related how these doctors would struggle to establish a diagnosis for the inmate to prevent him from being dispatched to a labour camp (Rejali, 2007).
It was after the death of Stalin in 1953 that the Communist Party of the USSR tried to establish a new less-repressive image. There was also increased monitoring of state activities by human rights groups and international bodies. This resulted in less repression associated with the Gulags and internal exile. This gathered pace after the development of the Helsinki Accords on Human Rights in 1973. It was during this period of time that psychiatric hospitals became a convenient place of incarceration for the removal of dissidents and the politically undesirable. These Soviet psycho-prisons were no longer considered the oasis of humanism as before. In the 24 May 1959 edition of the newspaper, Pravda, the Soviet leader, Nikita Khrushev, was quoted as saying 'A crime is a deviation from the generally recognized standards of behaviour frequently caused by mental disorder ... to those who might call for opposition to communism ... clearly the mental state of such people is not normal'. Soviet doctors no longer took the Hippocratic Oath. Instead, they took the Oath of the Soviet Doctor.

In order to facilitate the abuse of political psychiatry, it was necessary to expand the psychiatric classification system to include a new diagnostic category that would take into account those who in some way challenged the political power of the state. This was facilitated by the development of the concept of 'sluggish schizophrenia' by Dr Andrei Snezhnevsky, the director of the Institute of Psychiatry for the Soviet Union. He alleged that sluggish schizophrenia would demonstrate itself by personality changes that would require specialised psychiatric training to elicit. Its symptoms included anxiety, hypochondria, depersonalisation and psychopathy.

The main hospital that was utilised for the abuse of political psychiatry was the Serbski Institute for Forensic Psychiatry in Moscow. Its director was Dr Georgi Morozov who was an enthusiastic exponent on the diagnostic category of sluggish schizophrenia. When sluggish schizophrenia was challenged in 1979 by Dr Etely Kazanets, who also worked at the Serbski Institute, Dr Kazanets was fired from the Institute (Van Voren, 2010). Another diagnostic category created was 'reformist delusions', which was considered to be a form of paranoid schizophrenia (Wing, 1974). Other pathological signs of illness were a heightened sense of selfesteem or a failure to adapt to society (Bonnie, 2002). One of the most useful diagnostic categories is paranoid psychosis, which could be used as a label for those who are being hounded by the authorities. This tendency to overextend the diagnostic symptomatology of what is a genuine psychiatric diagnosis to those who are not suffering an illness is called hyper-diagnosis.

There are many heroes in the battle against the political abuse of psychiatry in the Soviet Union, but 
the one that has achieved most recognition is Vladamir Bukovsky. Even in 2012, at 70 years of age, he is battling the abuse of psychiatry in Putin's Russia. In 1971, he sent documentation in relation to the abuse of psychiatry in the Soviet Union to the World Psychiatric Association (WPA). When the issue was raised at the congress of the WPA in Mexico, the Soviet delegation threatened to walk out. The WPA backed down and the issue was not discussed. Bukovsky was subsequently sentenced to 7 years in a labour camp and 5 years in internal exile. Following this event, pressure began to mount on the WPA to take some form of action (Van Voren, 2002). This led to the WPA issuing its Declaration of Hawaii in 1977 (World Psychiatric Association, 1977). The most relevant paragraph of this document is Paragraph 7, which states:

The Psychiatrist must never use his professional possibilities to violate the dignity or human rights of any individual or group and should never let inappropriate personal desires or feelings prejudices or beliefs interfere with the treatment. The psychiatrist must on no account utilize the tools of his profession once the absence of psychiatric illness has been established. If a patient or some third party demand contrary to scientific knowledge or ethical principle, the psychiatrist must refuse to cooperate.

By this stage, the awareness of the widespread abuse of psychiatry in the USSR was so pervasive that the WPA threatened to eject their Soviet colleagues from the Association. Soviet Psychiatry was represented by the All Union Society. It withdrew from the WPA before its expulsion could be put to a vote in 1983. Their withdrawal was followed by the representative organisations of Czechoslovakia and Bulgaria, which were two client states of the USSR. Under perestroika and glasnost initiated by President Mikhail Gorbachov of the USSR, during the latter half of the 1980s, the abuse of psychiatry was openly discussed in the Soviet media. The All Union Society was subsequently readmitted in 1989 during the WPA congress in Athens. The Soviet delegation now openly admitted that abuses had occurred. They also promised to discontinue the abuses, rehabilitate the victims and democratise the All Union Society. Dr Yakov Landau, who ran the Fourth Department of the Serbski Institute for many years, when trying to explain his actions in relation to inappropriate detentions, is quoted as saying the Organs (KGB) burdened us with very responsible work, they expected us to do what they asked us to do and we knew what was expected' (Diamant, 1989). In 1988, the special forensic hospitals were transferred from the Ministry of Internal Affairs to the Ministry of Health. In 1991, a delegation from the WPA visited the Soviet Union and was allowed to inspect the psychiatric hospitals.
Behind the scenes working to bring to an end the political abuse of psychiatry was the Geneva Initiative on Psychiatry. It was working closely with Vladamir Bukovsky. It was formed in 1980, and in 2005 it was renamed the Global Initiative on Psychiatry. It has become one of the most important organisations for monitoring psychiatric abuses worldwide. It documented clear examples of abuse in psychiatry in 13 out of the 15 special psychiatric hospitals in the USSR.

\section{The Russian Federation}

In July 1992, after the demise of the Soviet Union, the Russian Federation developed progressive legislation in relation to involuntary admissions to psychiatric hospitals. The laws stated that such admissions should be based on 'medical indications, medical duty and law' (Bonnie \& Polubinskaya, 1999). By 2007, under the increasingly autocratic rule of Vladamir Putin, psychiatry had once again been used as a tool for getting rid of opponents and dissidents. The abuse is not to the same level as it was during the Soviet era, and the duration and conditions of involuntary detention are not at par with earlier times. Much of the abuse appears to be operating at a lower administrative level than previously. It still required the compliance of the local medical profession. Here are some examples of abuse that have garnered the interest of the foreign media.

Artem Basyrov (20 years) was placed in a psychiatric hospital in the Russian republic of Mar El. He was a member of the National Bolshevik Party and a candidate for the local legislature. He was due to partake in a 'Dissenter's March' on the 24 November 2007, the next day. Allegations were made that he was kept in isolation and not allowed any visitors (The Independent, London, 15 December 2007).

Sergei Ablamsky was a lawyer in Bryansk, 250 miles southwest of Moscow. He accused a local prosecutor of corruption. He was taken in handcuffs to a psychiatric institution where he was detained for 4 weeks. While there, he said he witnessed assaults by the staff on other patients. He said that he was heavily sedated (The Times, London, 26 August 2007).

Vasily Mikaelovich Stetsik was the editor of the journal, The Truth about Human Rights, in the town of Novotroitsk. The journal contained articles that were critical of the authorities. The journal's office was vandalised on a number of occasions and computers were stolen. In April 1998, he travelled to Moscow. He was arrested in a court room when he tried to pursue a human rights case. He was charged with attempted murder and taken to the Butyrka Pre-Trial Detention Centre in Moscow. He claimed that he was beaten there and he was left in a cold, damp, empty cell 
without food and medical treatment for 2 weeks. In December 1998, he was transferred to a psychiatric hospital in the Orenburg region. Neither Mr Stetsik nor his family have been given a reason for his detention in a psychiatric facility or his medical diagnosis (Amnesty International, 2002).

Sometimes old habits die hard. For this form of abuse to re-emerge again, there requires active acquiescence of a significant proportion of the mental health profession. When a profession has been through a dark period as psychiatry has in Russia, it can no longer claim ignorance or political indoctrination as it has in the past.

\section{The People's Republic of China}

To understand China and to understand the abuse of psychiatry in that country, you need to understand its history. Historically, in China, the authorities' concern for social cohesion and for social peace has been demonstrated when it has broken down. In its history, China has had two major rebellions that have led to massive losses of lives, estimated to be in the tens of millions. There was the Lotus rebellion in the 18th century and the Tao Ping rebellion in the 19th century. Both of these rebellions were driven by religious factors. This may explain the extreme repression that members of the Falun Gong, a lifestyle organisation, had to endure. It has been declared to be an 'evil cult' by the communist authorities. It does not explain why psychiatry is being used as a form of repression of its members and also for those who are deemed to be dissidents. China is the only country that specifically includes 'political harm to society' as a category that can be used by the medical and legal authorities to involuntary detain a person in a psychiatric institution.

During the early 1950s, there was a close political relationship between the USSR and the People's Republic of China. Dr Andrei Snezhnevsky's theory on sluggish schizophrenia was translated into Chinese. China developed special psychiatric hospitals that were run by the Ministry of Public Security. These were known as Ankangs (which means peace and happiness). There are an estimated 20 Ankang hospitals currently in existence in China. The larger institutions have a capacity for 1000 inmates. All of the staff are police officers, doctors and nurses. Once a person is admitted to an Ankang hospital, expert forensic psychiatric appraisal is supposed to be carried out. If a finding of legal non-imputability is being made, the public security authorities are then accorded complete control over the detention of the person and they are able to validate the compulsory psychiatric admission, with no input from the judicial system. As with their Soviet colleagues during the Stalinist era, the Chinese psychiatrist is in an ethical bind. If they were to find the defendant sane, and hence to be legally responsible for an alleged political offence, the defendant would then be at risk of receiving a long prison sentence in a labour camp, or else the death penalty. Sometimes, indefinite incarceration in an Ankang or a similar institution is the preferable option.

During the Cultural Revolution, everything including medicine was political. It lasted from 1966 until the death of Mao Tse Tung in 1975. During this period, it was promulgated in Chinese psychiatric literature that mental illness was 'inextricably linked to class struggle'. $^{\prime}$ The same literature noted that there was a higher level of mental illness to be found in the economically and socially deprived than in those that were better off (Human Rights Watch, Geneva Initiative on Psychiatry, 2002). In 1966, a patient wrote that 'In the past when the doctor told me that to cure your sickness you must be guided by correct ideology, I felt upset and offended. How could correcting one's ideology ever make one recover from mental illness? Would this not mean that in fact I had an ideological sickness (Human Rights Watch, Geneva Initiative on Psychiatry, 2002)?'

During the Cultural Revolution, it was reported that some forensic doctors submitted to political pressure and went against their own consciences in relation to the detention of the politically suspect in forensic psychiatric institutions (Haibo, 1993). Two years after the death of Mao, a study in 1977 carried out at the Hangzhou No: 7 People's Hospital demonstrated that $54 \%$ of the admissions were for anti-social political speeches and actions. By 1987, this figure was reduced to $6.7 \%$ (Munro, 2000a).

Complicating the abuse of mental health structures in China is the poor training of the psychiatrists and of the hospital administrators. There is a sense of obligation to accept anyone, sane or not, who is escorted by a government official. It was reported in 2010 that, because psychiatric hospitals, other than the Ankangs (run by the Ministry of the Interior), were under pressure to be self-financing, they were inappropriately detaining individuals who were problematic for their families, their employers or the local officials. As long as someone was paying the hospital fee, they were detained. They consisted of petitioners to the Government, dissidents and human rights activists. Allegations have been made of assaults, forced feeding, forced medication and electrocution of the detained (reported in the British Medical Journal, 3 July 2010).

Over the last two decades, inappropriate confinement to psychiatric hospital has been on the rise, as local authorities come under intense pressure to halt social unrest, while at the same time it has become increasingly difficult to detain those deemed to be socially and politically difficult using the legal system (New York Times, 11 November 2010). 
Since 1985, there have been 10 drafts at mental health law dealing with the issue of involuntary psychiatric detention and treatment. The Government of the People's Republic of China has yet to enact comprehensive legislation that safeguards the human rights of those who are involuntarily detained because of suspected mental illness. At the same time, Article 9 of the People's Republic of China's 1984 Supplementary Provisions Standing Committee of the National Peoples Congress in relation to the length of time a suspect can be held in custody when a mental disorder is suspected, specifies that the 1979 Criminal Law could be dispensed with for the period while the suspect is undergoing forensic psychiatric appraisal. As a result, a suspect can be indefinitely detained by utilising the psychiatric system without the complications of the legal system. It has been estimated that in China at least 3000 people have been sent to psychiatric hospitals for expressing political views in the 1980s and 1990s (Munro, 2000b).

\section{The Falun Gong}

The crackdown on the Falun Gong, a lifestyle organisation, was precipitated by a mass demonstration by an estimated 10000 practitioners outside the Zhongnanhai complex in April 1999, which is the main compound where the leading members of the Communist Party live and work. It caught the authorities by surprise. They had no intelligence input that it was to occur. This unnerved the authorities who have been historically wary about even quasi-religious organisations. Initially, Falun Gong was declared an evil cult. Then, to utilise psychiatry as a way of detaining members of the organisation, the Chinese psychiatric authorities created what they called a 'culture bound disorder'. They called the disorder 'qigong-induced' or 'qigong-related' disorder. Qigong is a traditional Chinese form of mind-body exercise that Falun Gong practitioners utilise. The authorities alleged that it caused a mental imbalance ranging from minor cognitive changes to a psychosis-like condition. This diagnosis was later changed to 'evil cult-induced mental disorder'. Since 1999, it has been estimated that 600 members have been incarcerated in psychiatric hospitals in an effort to get them to renounce their beliefs. Some have died in custody. They have been subjected to 'concentration reformation process', which involves making the victim renounce their beliefs in writing. It is reported that they have been subjected to ECT, inappropriate anti-psychotic drugs, sensory deprivation and physical restraint (Lyons \& O'Malley, 2002).

The WPA decided at the Twelfth World Congress in Yokohama, Japan, in 2002 to put forward a resolution calling on China to cooperate with an international investigation of the practice of psychiatry in that country. After months of negotiations with the Chinese Government and the Chinese Society of Psychiatrists (CSP), the Chinese Government postponed the visit, as it considered that the visit was more investigative than educational. Subsequently, in May 2004, the leadership of the WPA stated that the CSP acknowledged that there were some misdiagnoses and mistreatment of patients in the hospitals. As a result, there was no necessity for the investigative mission to China to go ahead (Muminovic, 2002). This rather startling decision was arrived at without a single investigator setting foot in China.

\section{Discussion}

History is fluid and unpredictable. We would be foolish not to believe that what has happened in these two large countries could not happen here at some time in the future. For this reason, all mental health professionals and those of the future must have an awareness of how these abuses can happen and an unwillingness to become part of a system that is oppressive. We need to know our history and the history of the profession throughout the world to aid us with continual vigilance. Psychiatry is particularly unique among the specialties of the medical profession in that it has the power to remove liberty. Only rarely, in cases of infectious diseases, is such power also present for other health professionals. One of the responsibilities is to ensure that no other person, state or non-state actors or organisations, bully, seduce or somehow suborn us into using this power for nonmedical purposes. The two countries' histories outlined above are not unique, but have received the most studies. The abuse of power to remove liberty has happened in the past in Ireland for social reasons. A time may come when attempts will be made to abuse that power for political purposes. It was not that long ago in the United Kingdom that the Royal College of Psychiatrists were fighting off an attempt to have preventative detention for those considered to have severe dangerous personality disorder. Political abuse of psychiatry can occur in more democratic systems, but such abuse can be ameliorated and weakened by a strong active and aware professional body of mental health professionals.

It is also incumbent upon us to advocate for those who are involuntarily detained in other countries for political reasons under the guise of mental illness. We have a duty to support our colleagues and others as they try to resist state pressure to behave unethically in detaining, for mental health reasons, the politically suspect. This we can do through our professional bodies such as the College of Psychiatrists of Ireland. 
We can work with the WPA and improve its quality of action in fighting the political abuse of psychiatry. There has been no acceptable clear explanation as to why the WPA pulled back from an investigative mission into the psychiatric hospitals in China. If we are involved more actively with this association and the Global Initiative on Psychiatry, we will be better placed to ask the questions and influence the direction that they take to ensure that those who lose their freedom for mental health reasons do so for the right reasons and have humane treatment.

\section{Acknowledgement}

The author thank Ms Sibeal Farrell for her help with the preparation of this manuscript.

\section{References}

Amnesty International (2002). Medical Action: Vasily Stetsik, human rights activist held in psychiatric hospital, Russian Federation, AI Index: EUR 46/017/2002.

Bloch S, Chadoff P (1991). Psychiatric Ethics, 2nd edn. Oxford University Press: England, p. 495.

Bloch S, Reddaway P (1977). Russia's Political Hospitals. Gollanz Press: UK.

Bonnie RJ (2002). Political abuse of psychiatry in the Soviet Union and in China: complexities and controversies. The Journal of the American Academy of Psychiatry and the Law 30, 136-144.

Bonnie RJ, Polubinskaya SV (1999). Unravelling Soviet Psychiatry. The Journal of Contemporary Legal Issues 10, 292-294.

British Medical Association (1992). Medicine Betrayed: Report of a Working Party. Zed Books: London, p. 64.

Daes E-I (1986). Principles, guidelines and guarantees for the protection of persons detained on grounds of mental ill health or suffering from mental disorder, UN Doc. E/CN.4/Sub/1983/17/rev.

Diamant LN (1989). Issues in clinical evaluation and compulsory treatment of psychopathic personalities with paranoid delusions and overvalued ideas: cited in Gluzman, On Soviet totalitarian Psychiatry, pp. 39-44,
International Association on the Political use of Psychiatry.

Gordon H, Meux R (2000). Forensic psychiatry in Russia: past, present and future. Psychiatric Bulletin 24, 121-123.

Haibo Z (1993). On the fundamental principles and methods of forensic medical investigations. China's Forensic Medical Practice, 47-48.

Hickling FW (2002). The political misuse of psychiatry: an African-Caribbean perspective. The Journal of the American Academy of Psychiatry and the Law 30, 116.

Human Rights Watch, Geneva Initiative on Psychiatry (2002). Dangerous Minds: political psychiatry in China today and its origins in the Mao era, p. 23.

Lyons D, O'Malley A (2002). The labelling of dissent: politics and psychiatry behind the Great Wall. Psychiatric Bulletin 26, 443-444.

Medvedev Z, Medvedev R (1971). A Question of Madness. McMillan: London, pp. 196-197.

Muminovic M (2002). Psychiatric Association to investigate abuse in China. British Medical Journal 325, 513.

Munro R (2000a). Judicial psychiatry in China and its political abuses. Columbian Journal of Asian Law 14, 27.

Munro R (2000b). Political Psychiatry in China: A First Glance at the Documentary Evidence. Geneva Initiative on Psychiatry: Hilversum, Holland, pp. 1-22.

Njenga F (2002). Focus on psychiatry in East Africa. British Journal of Psychiatry 181, 354-359.

Ougrin D, Gluzman S, Dratcu L (2006). Psychiatry in postcommunist Ukraine: dismantling the past, paving the way for the future. Psychiatric Bulletin 30, 456-459.

Rejali D (2007). Torture and Democracy. Princeton University Press: New Jersey, p. 393.

Van Voren R (2002). Comparing Soviet and Chinese political psychiatry. Journal of the American Academy of Psychiatry and the Law 50, 131-135.

Van Voren R (2010). Cold War in Psychiatry: Human Factors, Secret Actors. Rodopi: New York, pp. 103-104.

Wing J (1974). Psychiatry in the Soviet Union. British Medical Journal 9, 433-436.

World Psychiatric Association (1977). Declaration of Hawaii, adopted by the General Assembly in 1997 at the 6th World Congress of Psychiatry in Honolulu, Hawaii. 